DOI 10.22460/jpmi.v1i3.333-346

\title{
ANALISIS KEMAMPUAN BERPIKIR KREATIF MATEMATIS DITINJAU DARI KEPERCAYAAN DIRI SISWA SMP KELAS VIII DI KOTA CIMAHI PADA MATERI BANGUN DATAR SEGI EMPAT
}

\author{
Keni Eviliasani ${ }^{1}$, Heris Hendriana ${ }^{2}$, Eka Senjayawati ${ }^{3}$ \\ 1,2,3 IKIP Siliwangi, Jl. Terusan Jenderal Sudirman, Cimahi, Jawa Barat, Indonesia \\ ${ }^{1}$ keni.eviliasani@gmail.com, ${ }^{2}$ herishen@ikipsiliwangi.ac.id, ${ }^{3}$ ekasenjayawati@ikipsiliwangi.ac.id
}

Diterima: 23 Maret 2018; Disetujui: 28 Mei 2018

\begin{abstract}
This study aims to analyze the ability of mathematical creative thinking in terms of student selfconfidence in learning mathematics on the matter of building a rectangular flat. In this study using descriptive method with qualitative approach by analyzing the level of mathematical creative thinking seen from the level of student confidence. The population of this research is 30 students of class VIII in Senior High School of 3 Cimahi academic year 2017-2018. The results of this study show that students who have high self-esteem (KDT) will have a high creative thinking ability, students who have moderate confidence (KDS) will have the ability to think creatively that, as well as students who have low self-confidence will have low creative thinking ability.
\end{abstract}

Keywords: Mathematical Creative Thinking, Self Confidence, Rectangular Two-Dimentional Figure

\begin{abstract}
Abstrak
Penelitian ini bertujuan untuk menganalisis kemampuan berpikir kreatif matematis ditinjau dari kepercayaan diri siswa dalam pembelajaran matematika pada materi bangun datar segiempat. Dalam penelitian ini menggunakan metode deskriptif dengan pendekatan kualitatif dengan menganalisis tingkat berpikir kreatif matematis yang dilihat dari tingkat kepercayaan diri siswa. Populasi penelitian ini adalah 30 siswa kelas VIII di SMP Negeri 3 Cimahi tahun ajaran 2017-2018. Hasil penelitian ini menunjukan bahwa siswa yang memiliki kepercayaan diri tinggi (KDT) akan memiliki kemampuan berpikir kreatif yang tinggi, siswa yang memiliki kepercayaan diri sedang (KDS) akan memiliki kemampuan berpikir kreatif yang sedang, begitu pula dengan siswa yang memiliki kepercayaan diri rendah akan memiliki kemampuan berpikir kreatif yang rendah.
\end{abstract}

Kata Kunci: Berpikir Kreatif Matematis, Kepercayaan Diri, Bangun Datar Segi Empat

How to cite: Eviliasani, K., Hendriana, H., \& Senjayawati, E. (2018). Analisis Kemampuan Berpikir Kreatif Matematis ditinjau dari Kepercayaan Diri Siswa SMP Kelas VIII di Kota Cimahi pada Materi Bangun Datar Segi Empat. JPMI - Jurnal Pembelajaran Matematika Inovatif, 1 (3), 333-346.

\section{PENDAHULUAN}

Matematika merupakan ilmu pasti yang hakikatnya menjadi dasar dari ilmu lain, sehingga matematika itu saling berkaitan dengan ilmu lainnya. Matematika adalah kunci ke arah peluang-peluang, jadi bagi seorang siswa yang berhasil mempelajarinya maka akan membuka pintu karir yang cemerlang. Tidak sedikit siswa yang menganggap bahwa tujuan matematika hanya untuk keperluan kehidupan sehari-hari. Ternyata bukan hanya itu saja, tetapi 
matematika diajarkan pada dasarnya bertujuan untuk melatih pola pikir siswa agar dapat memecahkan masalah dengan kreatif, kritis, logis dan tepat. Oleh karena itu matematika sangat penting dan dipelajari pada tiap jenjang pendidikan, hal ini ditegaskan oleh (Widiyanti, 2011) menyatakan bahwa "Matematika sebagai bahasa fungsi praktis simbiolis untuk mengekspresikan hubungan kuantitatif dan spasial dimana fungsi teoritisnya untuk memfasilitasi berpikir merupakan hal yang perlu dipelajari dalam pendidikan."

Salah satu kemampuan matematis tingkat tinggi untuk menghadapi permasalahan, baik dalam matematika maupun kehidupan nyata adalah kemampuan berpikir kreatif. (Mahmudi \& Sumarmo, 2004) mendefinisikan berpikir kreatif sebagai proses kontruksi ide yang menekankan pada aspek kelancaran, keluwesan, kebaruan, dan keterincian. Maka hal tersebut menunjukan bahwa kemampuan berpikir seseorang akan dipicu oleh masalah-masalah yang menantang. (Ayuni, Firmansyah, Senjayawati, \& Maya, 2018) menguraikan indikator berpikir kreatif secara rinci sebagai berikut: 1)Kelancaran (Fluency); 2)Kelenturan (Flexibelity); 3)Keaslian (Originality); 4)Elaborasi (Elaboration). Hal ini diperjelas oleh pendapat (Eftafiyana, Nurjanah, Armania, Sugandi, \& Fitriani, 2018) menjelaskan bahwa kelancaran (fluency) mengacu pada kemampuan siswa dalam memberikan bermacam-macam jawaban, fleksibilitas (flexiblity) mengacu pada kemampuan siswa dalam menyelesaikan masalah tidak dengan satu cara tetapi bisa memberikan cara lain, keaslian (originality) mengacu pada kemampuan siswa melahirkan ungkapan baru dan unik, dan elaborasi (elaboration) mengacu pada kemampuan siswa untuk mampu memperkaya atau mengembangkann suatu gagasan (Dilla, Hidayat, \& Rohaeti, 2018; Hendriana, Rohaeti, \& Hidayat, 2017; Hendriana, Hidayat, \& Ristiana, 2018; Hidayat, 2011; 2012; Sumarmo, Hidayat, Zukarnaen, Hamidah, \& Sariningsih, 2012).

Salah satu aspek kepribadian yang menunjukkan sumber daya manusia yang berkualitas adalah tingkat kepercayaan diri seseorang. Kepercayaan diri berfungsi penting untuk mengaktualisasikan potensi yang dimiliki oleh seseorang (Rahmi, Nadia, Hasibah, \& Hidayat, 2017; Sumarmo, Mulyani, \& Hidayat, 2018). Kepercayaan diri berkembang dari kegiatan dan tindakan yang dilakukan oleh individu, dari mencoba daripada menghindari situasi dan bersikap pasif terhadap kondisi yang dihadapinya. Kepercayaan diri yang positif akan menambah semangat dan kemampuan berpikir untuk merasa yakin dengan kompetensi yang telah dimiliki, hal ini akan mendorong seseorang untuk berusaha semaksimal mungkin sesuai dengan tujuan yang akan dicapai yaitu meraih prestasi belajar yang baik. Menurut (Hendriana, 2012) dalam buku Hard Skills dan Soft Skills kepercayaan diri merupakan suatu sikap atau perasaan yakin atas kemampuan diri sendiri sehingga orang yang bersangkutan tidak terlalu cemas dalam tindakan-tindakannya, dapat merasa bebas untuk melakukan hal-hal yang disukainya, dan bertanggung jawab atas tindakannya, hangat dan sopan dalam berinteraksi dengan orang lain, memiliki dorongan untuk berprestasi serta mengenal kelebihan dan kekurangan dirinya. Adapun indikator kepercayaan diri siswa menurut (Hendriana, 2012) meliputi: a) Percaya kepada kemampuan sendiri; b) Selalu bersikap positif dalam menghadapi masalah; c) Bertindak mandiri dalam mengambil keputusan; d) Memiliki konsep diri yang positif; e) Berani mengungkapkan pendapat.

Pada kenyataan di lapangan banyak siswa menganggap matematika adalah pelajaran yang sangat sulit untuk dipecahkan. Berdasarkan hasil wawancara pada siswa SMP lebih banyak siswa yang merasa kurangnya kepercayaan diri dalam pembelajaran matematika, karena mereka berpandangan bahwa matematika merupakan pelajaran dengan sejuta rumus. Kurangnya kepercayaan diri siswa dalam mengikuti pembelajaran matematika, dapat mempengaruhi tujuan pembelajaran yang diharapkan. Dan faktanya siswa menganggap 
belajar matematika tidaklah penting. Ini ditunjukan oleh sebuah hasil penelitian internasional dalam bidang matematika dan sains Programe for Internasional Student Assesment (PISA) tahun 2012 (Eftafiyana et al., 2018) negara Indonesia menduduki peringkat 64 dari 65 negara, sehingga hal ini menujukkan kondisi kepercayaan diri siswa dalam berkemampuan tingkat tinggi khususnya kemampuan berpikir kreatif rendah.

Dalam menyelesaikan permasalahan yang berkaitan dengan kemampuan berpikir kreatif, sering ditemukan beberapa kesalahan sehingga diperlukannya analisis kemampuan berpikir kreatif yang dilihat dari tingkat kepercayaan diri siswa. Kemampuan berpikir kreatif siswa juga dapat di identifikasi dengan pemberian soal dengan materi segi empat (Matematika, 1997). Karena materi segiempat pada SMP kelas VII membahas tentang macam-macam segiempat yaitu ada trapesium belah ketupat dan layang-layang yang memungkinkan siswa untuk menghasilkan ide-ide baru.

Berdasarkan uraian yang telah dipaparkan, terdapat masalah yang cukup menarik untuk diteliti. Sehingga peneliti ingin menganalisis kemampuan berpikir kreatif matematis ditinjau dari kepercayaan diri siswa SMP pada materi bangun datar segi empat.

\section{METODE}

Metode penelitian yang digunakan dalam penelitian ini adalah deskriptif dengan pendekatan kualitatif, dengan populasinya adalah sebanyak 30 siswa kelas VIII-E SMP Negeri 3 Cimahi. Instrumen dalam penelitian ini berupa instrumen nontes yaitu berupa angket kepercayaan diri siswa, dan juga soal tes kemampuan berpikir kreatif. Tahap awal yang dilakukan oleh peneliti adalah menyusun angket kepercayaan diri siswa yang bersumber dari (Hendriana, 2012) yang terdiri dari 30 soal dan 5 indikator.

Tabel 1. Kisi-Kisi Skala Kepercayaan Diri Siswa

\begin{tabular}{|c|c|c|c|c|}
\hline \multirow{2}{*}{ No } & \multirow{2}{*}{ Indikator Self Confidence } & \multicolumn{2}{|c|}{ Pernyataan } & \multirow{2}{*}{ Jumlah Soal } \\
\hline & & Positif & Negatif & \\
\hline 1. & $\begin{array}{l}\text { Yakin dengan kemampuan diri } \\
\text { sendiri }\end{array}$ & $4,8,10,24$ & $3,5,9,20,26$ & 9 \\
\hline 2 & $\begin{array}{l}\text { Selalu bersikap positif dalam } \\
\text { menghadapi masalah }\end{array}$ & $15,17,19,21$ & 6,14 & 6 \\
\hline $\begin{array}{l}3 \\
3 .\end{array}$ & $\begin{array}{l}\text { Bertindak mandiri dalam } \\
\text { menghadapi } \\
\text { Keputusan }\end{array}$ & $13,25,27$ & 7,28 & 5 \\
\hline 4. & Memiliki konsep diri yang positif & 2 & $11,12,16,18,22$ & 6 \\
\hline 5. & Berani mengungkapkan pendapat & $1,23,29$ & 30 & 4 \\
\hline & Jumlah Butir & 15 & 15 & 0 \\
\hline
\end{tabular}

Sumber: (Hendriana, 2012)

Setiap pertanyaan terdiri dari empat alternatif jawaban, yaitu sangat setuju (SS), setuju (S), tidak setuju (TS), dan sangat tidak setuju (STS). (Ruseffendi, 2006) Untuk penskoran masingmasing pernyataan positif berturut-turut $4,3,2,1$ dan sebaliknya untuk pernyataan negatif. Analisa data dalam penelitian ini adalah teknik analisis presentase, dengan rumus sebagai berikut. (Muhamad, 2017). 
336 Eviliasani, Hendriana, \& Senjayawati, Analisis Kemampuan Berpikir Kreatif Matematis ...

$$
P=\frac{f}{n} \times 100 \%
$$

Keterangan :

$\mathrm{P}=$ Presentase Siswa

$\mathrm{F}=$ Skor Siswa

$\mathrm{N}=$ Jumlah Skor Maksimal Siswa

Setelah dihitung persentasenya, kemudian lihat pada tabel klasifikasi kepercayaan diri siswa. (Surya, Putri, \& Mukhtar, 2017)

Tabel 2. Klasifikasi Tingkat Kepercayaan Diri Siswa

\begin{tabular}{clc}
\hline No. & \multicolumn{1}{c}{ Klasifikasi } & Persentase \\
\hline 1. & Sangat Baik & $81 \%-100 \%$ \\
2. & Baik & $61 \%-80 \%$ \\
3. & Kurang Baik & $41 \%-60 \%$ \\
4. & Tidak Baik & $21 \%-40 \%$ \\
5. & Sangat Tidak Baik & $0 \%-20 \%$ \\
\hline
\end{tabular}

Setelah menguji tingkat kepercayaan diri siswa, peneliti memilih 3 sampel siswa yang terdiri dari siswa yang memiliki kepercayaan diri tinggi, sedang, dan rendah. Kemudian peneliti menguji kemampuan berpikir kreatif siswa yang terdiri dari 5 soal yang sudah diuji validitas, reabilitas, dan indeks kesukarannya.

\section{HASIL DAN PEMBAHASAN}

Hasil

Tabel 3. Persentase Kepercayaan Diri Siswa

\begin{tabular}{cccccccccccc}
\hline \multirow{2}{*}{ Siswa } & $\begin{array}{c}\text { \% } \\
\text { KD }\end{array}$ & \multirow{2}{*}{ Siswa } & $\begin{array}{c}\text { \% } \\
\text { KD }\end{array}$ & Siswa & $\begin{array}{c}\text { \% } \\
\text { KD }\end{array}$ & Siswa & $\begin{array}{c}\text { \% } \\
\text { KD }\end{array}$ & Siswa & $\begin{array}{c}\text { \% } \\
\text { KD }\end{array}$ & Siswa & $\begin{array}{c}\text { \% } \\
\text { KD }\end{array}$ \\
\hline S1 & $18 \%$ & S6 & $17 \%$ & S11 & $19 \%$ & S16 & $40 \%$ & S21 & $81 \%$ & S26 & $45 \%$ \\
S2 & $35 \%$ & S7 & $79 \%$ & S12 & $40 \%$ & S17 & $25 \%$ & S22 & $60 \%$ & S27 & $38 \%$ \\
S3 & $50 \%$ & S8 & $39 \%$ & S13 & $15 \%$ & S18 & $55 \%$ & S23 & $19 \%$ & S28 & $75 \%$ \\
S4 & $40 \%$ & S9 & $80 \%$ & S14 & $45 \%$ & S19 & $18 \%$ & S24 & $37 \%$ & S29 & $39 \%$ \\
S5 & $60 \%$ & S10 & $59 \%$ & S15 & $29 \%$ & S20 & $65 \%$ & S25 & $83 \%$ & S30 & $82 \%$ \\
\hline
\end{tabular}

Berdasarkan Tabel 3, kepercayaan diri 30 siswa kelas VIII-E SMPN 3 Cimahi masih tergolong rendah dengan perolehan persentase terendah $15 \%$ dan persentase tertinggi $83 \%$. Data tersebut diolah berdasarkan teknik analisis persentase(Muhamad, 2017). Maka, setelah itu, data diklasifikasikan sesuai dengan tingkat kepercayaan diri siswa (Surya et al., 2017) dalam grafik berikut. 


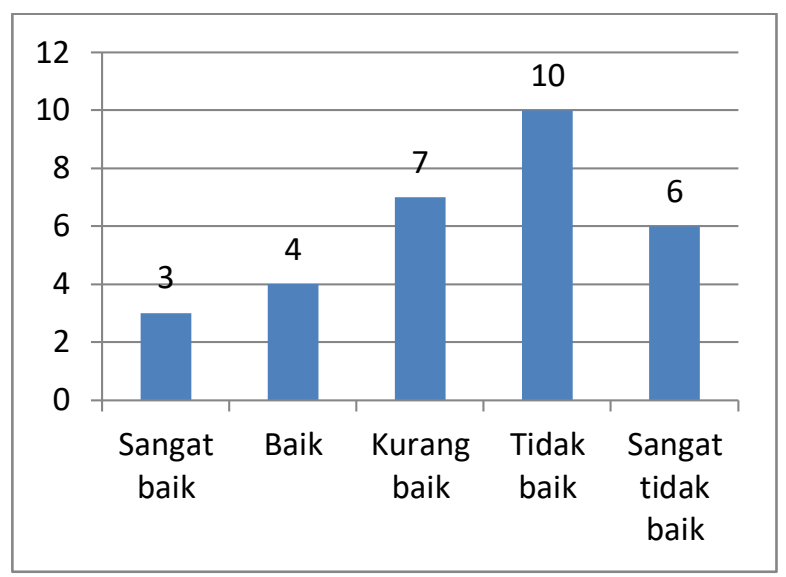

Grafik 1. Tingkat Kepercayaan Diri Siswa

Berdasarkan Grafik 1, kepercayaan diri siswa kelas VIII-E SMPN 3 Cimahi 3 orang memiliki kepercayaan diri tinggi (KPT), 11 orang memiliki kepercayaan diri sedang (KPS), dan 16 orang memiliki kepercayaan diri rendah (KPR).

Penelitian ini dilakukan untuk menganalisis tingkat kemampuan berpikir kreatif ditinjau dari kepercayaan diri siswa SMP, maka peneliti memilih 3 orang siswa yang diantaranya siswa I yaitu S25 yang memiliki kepercayaan diri tinggi (KDT), siswa II yaitu S12 yang memiliki kepercayaan diri sedang (KDS) sedang dan siswa III yaitu S6 yang memiliki kepercayaan diri rendah (KDR).

\section{Pembahasan}

\section{Analisis Soal No. 1}

Pertanyaan no 1: Buatlah dua bangun datar lain yang luasnya sama dengan bangun jajargenjang dengan alas $8 \mathrm{~cm}$ dan tinggi $4 \mathrm{~cm}$.

Indikator : Siswa dapat menghasilkan banyak ide dalam berbagai kategori. (Fluency/Kelancaran)

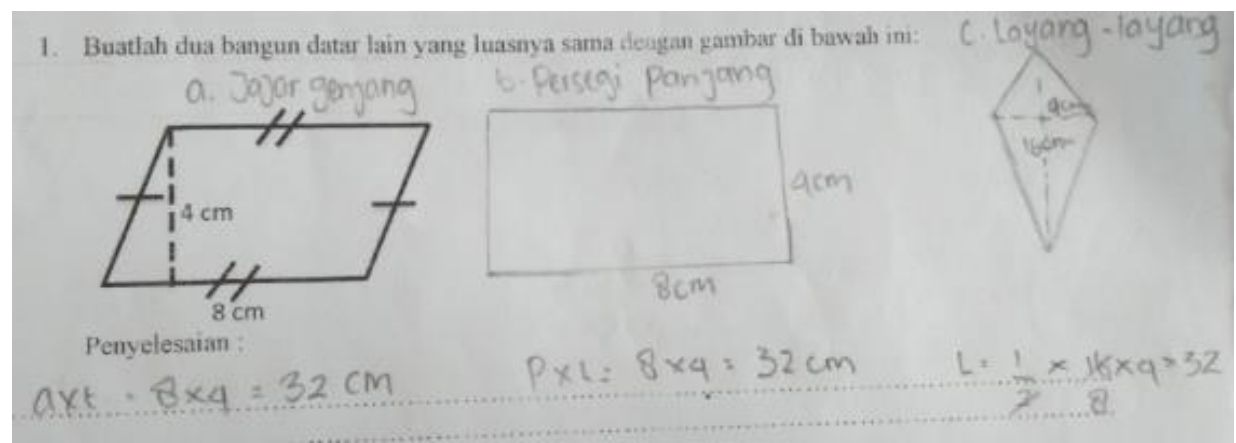

Gambar 1. Jawaban Siswa 1

G : "Dari soal no 1 apa yang ditanyakan ?"

SI : : Tentukan bangun datar lain yang luasnya sama, bu."

G : "Selanjutnya, langkah apa yang harus kamu lakukan ?"

SI : "Tinggal hitung luas jajargenjangnya dan cari bangun lain yang luasnya sama" 
G : "Apakah bangun lain yang luasnya sama pasti memiliki sisi yang sama?”

SI : "Ya, bu karena luas jajargenjang hanya mengalikan alas dan tingginya sama seperti bangun persegi panjang yang hanya mengalikan sisi panjang dan sisi lebarnya"

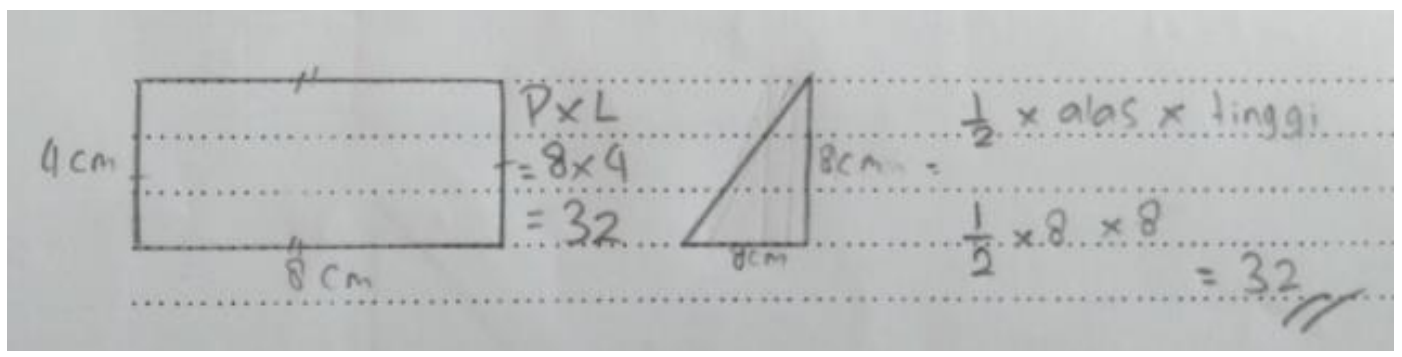

Gambar 2. Jawaban Siswa 2

G :"Coba perhatikan apakah hanya bangun segiempat saja yang memuat luas yang sama?"

SII : "Menurut saya tidak bu, bangun segitiga juga bisa"

G :"Apakah panjang sisinya sama seperti panjang sisi jajar genjang?”

SII :"Tidak bu, karena rumus luas segitiga harus dikali setengah jadi salah satu sisinya harus ada yang dikali setengah"

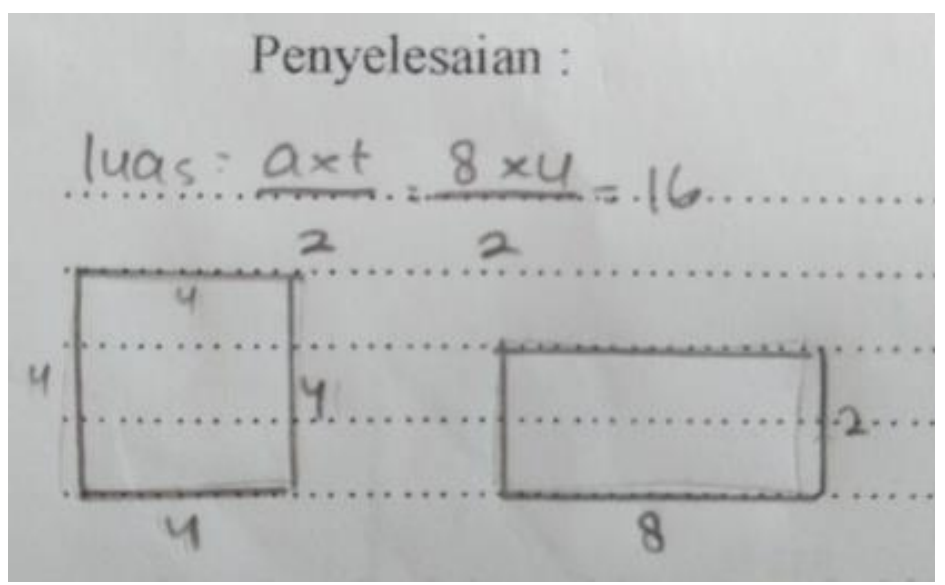

Gambar 3. Jawaban Siswa 3

G : "Coba perhatikan apakah jawaban yang kamu tulis itu benar ?”

SIII : "Menurut saya benar bu, ada apa bu?"

G : :Coba perhatikan apa yang ditanyakan!"

SIII :"Buatlah bangun lain yang luasnya sama"

G : "Apakah benar luas jajar genjang seperti itu?"

SIII : "Saya yakin apabila rumus luas jajar genjang itu $1 / 2 \mathrm{x}$ a $\mathrm{x}$ "

Berdasarkan hasil wawancara dan hasil jawaban siswa pada nomer 1, dapat ditarik kesimpulan bahwa siswa I (KDT) dan II (KDS) berkemampuan tingkat tinggi untuk indikator 
fluency yaitu menghasilkan bermacam-macam solusi. Sedangkan pada siswa III (KDR) masih berkemampuan fluency yang rendah ditunjukkan dari siswa mengalami kesulitan dalam mengingat rumus luas suatu bangun datar sehingga menurunkan kemampuan siswa menyelesaikan masalah matematika dengan berbagai jawaban.

\section{Analisis Soal No. 2}

Pertanyaan no. 2: Gambarlah segitiga sama kaki $A B C$ dan ACD yang kongruen, segitiga itu berimpit di $A C$, jika $A B=B C=C D=A D$ panjang $A C=8 \mathrm{~cm}$ dan panjang $B D=10 \mathrm{~cm}$. Ungkapkanlah bagaimana cara kamu mencari luas daerah $A B C D$ dengan menggunakan prinsip atau rumus yang berbeda, paling sedikit 2 cara.

Indikator : Siswa dapat menghasilkan banyak ide dalam berbagai kategori. (Fluency/Kelancaran)

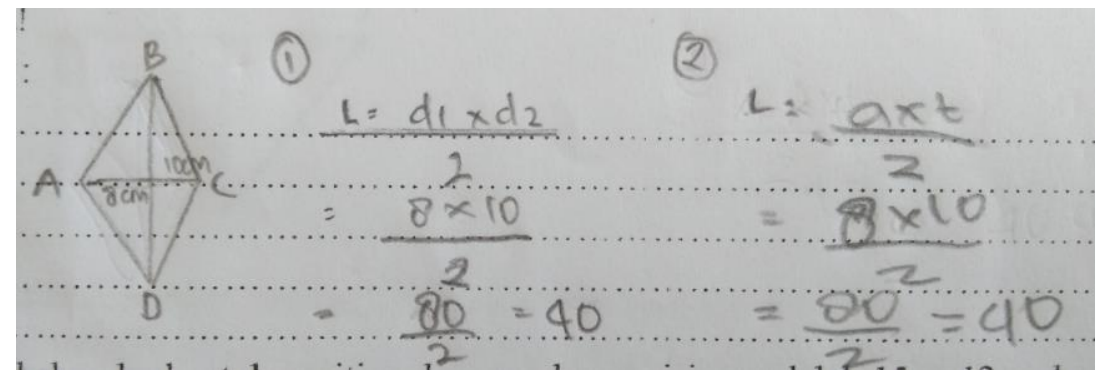

Gambar 4. Jawaban Siswa 1

G : "apakah ada kesulitan pada soal no2 ?"

SI :"tidak bu, saya mengerti dengan apa yang ditanyakan. Hanya saja saya kesulitan ketika diminta dengan menggunakan cara lain"

G : "bangun apa yang sebenarnya terbentuk dari keterangan soal diatas?"

SI : "layang-layang, bu"

G : "layang-layang itu terdiri dari bangun apa saja?"

SI : "segitiga, bu"

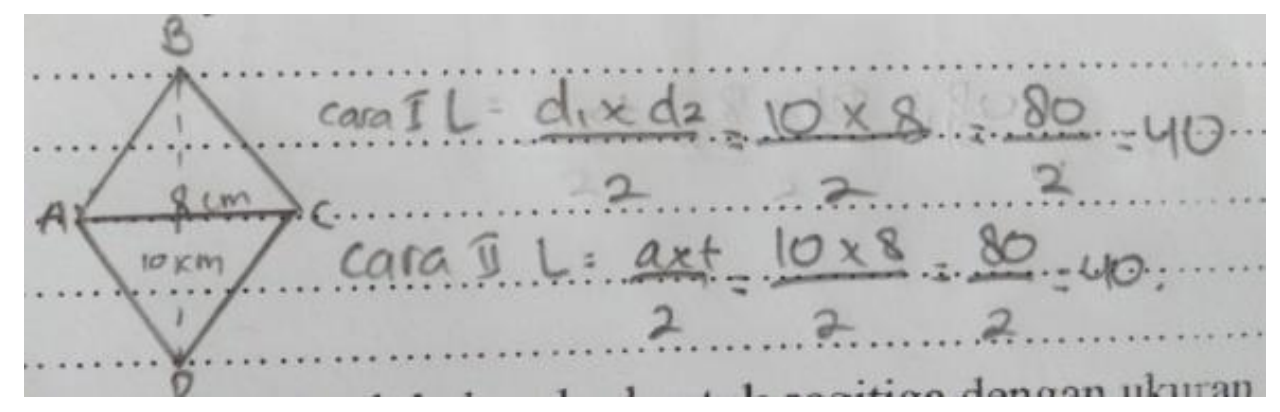

Gambar 5. Jawaban Siswa 2

G : “Apakah bisa mengerjakan soal no.2?”

SII : "Masih bingung bu dalam membedakan bangun laying-layang dan belah ketupat" 
G : "Menurutmu, bangun apa yang sebenarnya terbentuk dari keterangan soal diatas?"

SII : "belah ketupat, bu"

G : "bagimanakah sifat belah ketupat?"

SII : "bingung, bu"

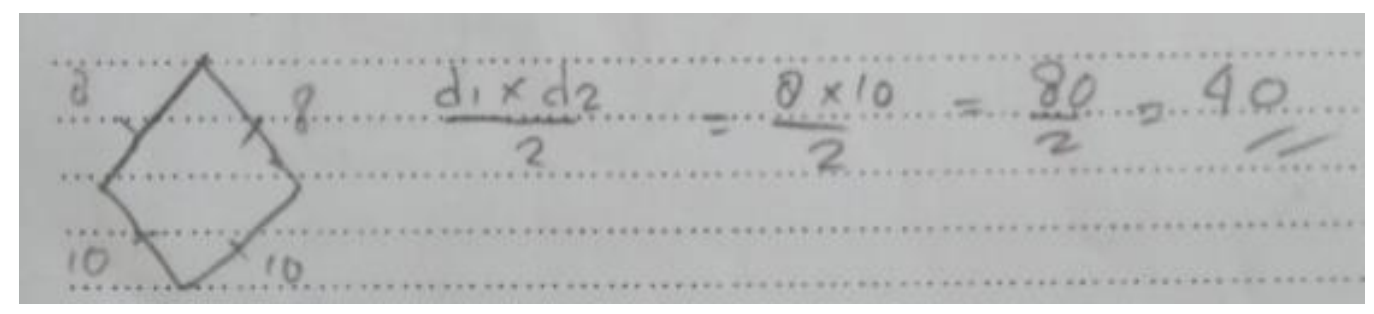

Gambar 6. Jawaban Siswa 3

G : "Coba perhatikan apakah gambar yang kamu tulis itu benar ?"

SIII : "Menurut saya benar bu, ada apa bu?"

G : :Coba perhatikan apakah ukuran sisinya tepat seperti apa yang diketahui dalam soal?”

SIII :'Iya, bu"

Berdasarkan hasil wawancara dan hasil jawaban siswa pada nomer 2, dapat ditarik kesimpulan bahwa siswa I (KDT) berkemampuan kreatif tingkat sedang dalam indikator flexibility karena siswa masih kesulitan dalam mempartisibangun datar kedalam bentuk bangun datar lain. Untuk siswa II (KDS) dan III (KDR) masih rendah pada kemampuan flexibility karena masih bingung dalam membedakan bangun layang-layang dan belah ketupat serta kesulitan dalam menempatkan nilai sisi yang diketahui.

\section{Analisis Soal No. 3}

Pertanyaan no. 3: Pada sebuah kebun berbentuk segitiga dengan ukuran sisinya adalah 15m, $12 \mathrm{~m}$, dan $8 \mathrm{~m}$. Sekeliling itu ditanami pohon jeruk dengan jarak antara pohonnya $1 \mathrm{~m}$. Bagaimana kamu menghitung banyak pohon jeruk di sekeliling kebun itu.

Indikator : Siswa memiliki ide-ide baru untuk memecahkan persoalan (Originallity/Keaslian)

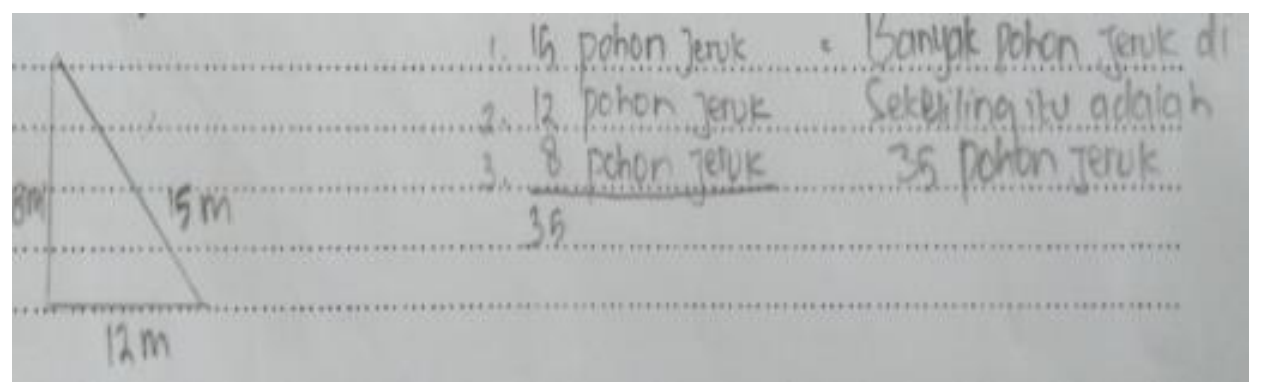

Gambar 7. Jawaban Siswa 1 
G : "apakah ada kesulitan pada soal no2 ?"

SI :'tidak bu, saya mengerti dengan apa yang ditanyakan."

G :"konsep apa yang dipakai dalam menyelesaikan soal ini?"

SI : "konsep keliling segitiga, bu"

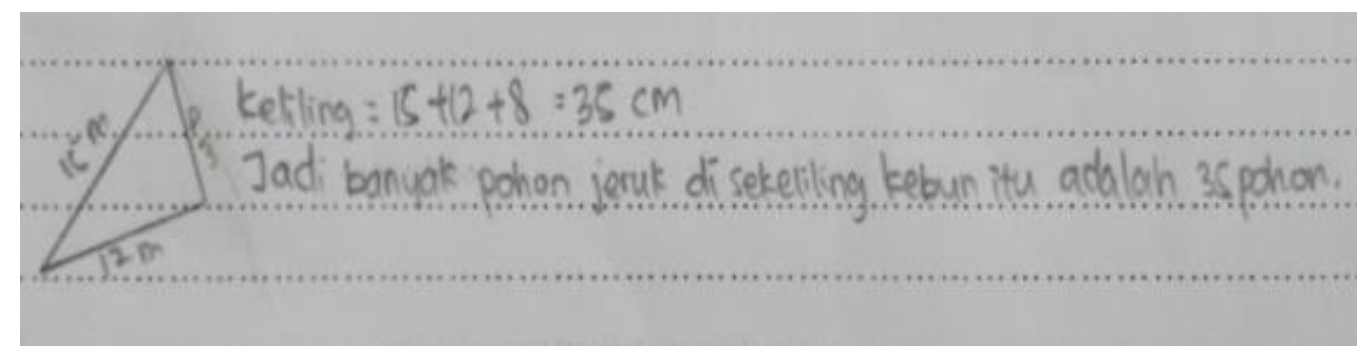

Gambar 8. Jawaban Siswa 2

G : “Apakah bisa mengerjakan soal no.2 ?”

SII : "Bisa, tidak ada kesulitan, bu"

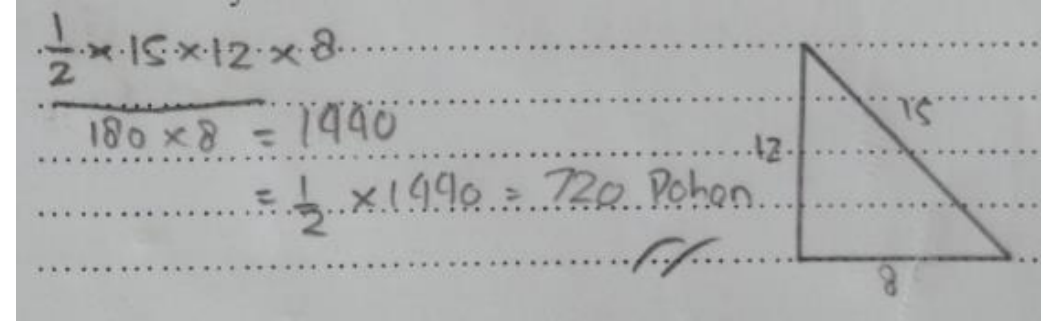

Gambar 9. Jawaban Siswa 3

G : "apakah terdapat kesulitan untuk soal no 3 ?"

SIII : "saya kurang paham bu dengan apa yang ditanyakan pada soal."

G : "coba baca soalnya apa yang ditanyakan ?"

SIII : "tentukan banyak pohon disekeliling kebun"

G : "ya, selanjutnya apa yang dikerjakan?"

SIII : "luas segitiga itu apa bu rumusnya? Saya lupa"

G : "coba tanyakan pada temannya! Lalu coba fikirkan apa jawaban yang tepat untuk soal ini"

SIII : "baik bu."

Berdasarkan hasil wawancara dan hasil jawaban siswa pada nomer 3, dapat ditarik kesimpulan bahwa siswa I (KDT) dan II (KDS) berkemampuan tingkat tinggi dalam indikator originallity karena siswa masih tidak mengalami kesulitan dalam menyelesaikan soal dan mengetahui konsepnya. Untuk siswa III (KDR) masih rendah pada kemampuan originallity 
karena masih bingung dalam membedakan konsep luas dan keliling bangun datar dalam kehiduapan sehari-hari.

\section{Analisis Soal No. 4}

Pertanyaan no. 4: Haikal sedang bermain plastisin, dia hendak membuat bangun datar segiempat, dimana panjang setiap sisinya $10 \mathrm{~cm}$ dan setiap sudut dari sisi bangun datar tersebut adalah sudut siku-siku.

a. Bangun apakah yang terbentuk? Gambarkan!

b. Apabila Haikal hendak membuat segiempat kedua di dalam gambar tersebut dengan menghubungkan masing-masing titik tengah pada setiap sisimya. Bangun apakah yang terbentuk? Gambarkan bangun di soal nomer a.

c. Apabila Haikal ingin membuat segiempat ketiga di dalam gambar kedua dengan menghubungkan masing-masing titik tengah pada setiap sisinya. Bangun apakah yang terbentuk? Gambarkanlah bangun tersebut di soal nomer a.

d. Bagaimana cara menghitung luas dan keliling bangun ke III?

Indikator : Siswa memiliki ide-ide baru untuk memecahkan persoalan (Originallity/Keaslian)

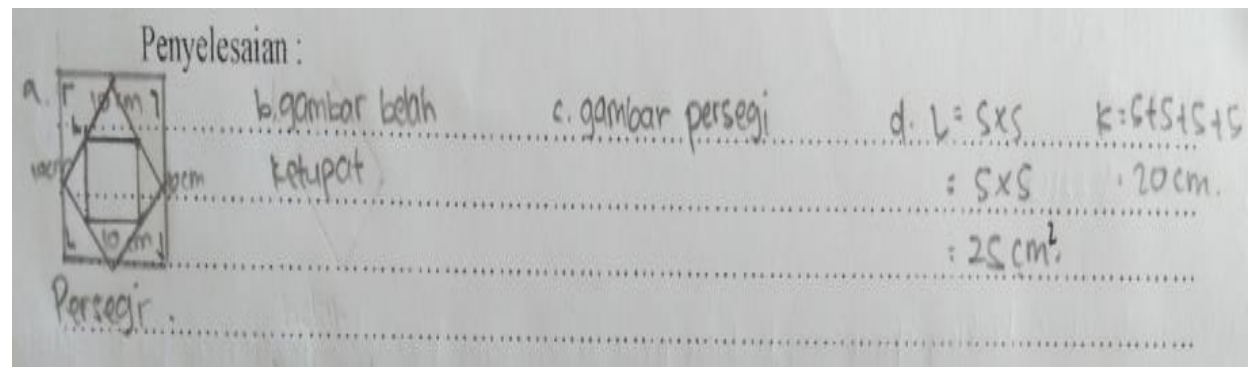

Gambar 10. Jawaban Siswa 1

G : "apakah terdapat kesulitan untuk soal no 3 ?"

SI : "tidak ada, bu. Saya bisa."

G : "Darimanakah kamu mengetahui nilai sisi pada bangun ketiga?"

SI : "dengan konsep phytagoras, bu"

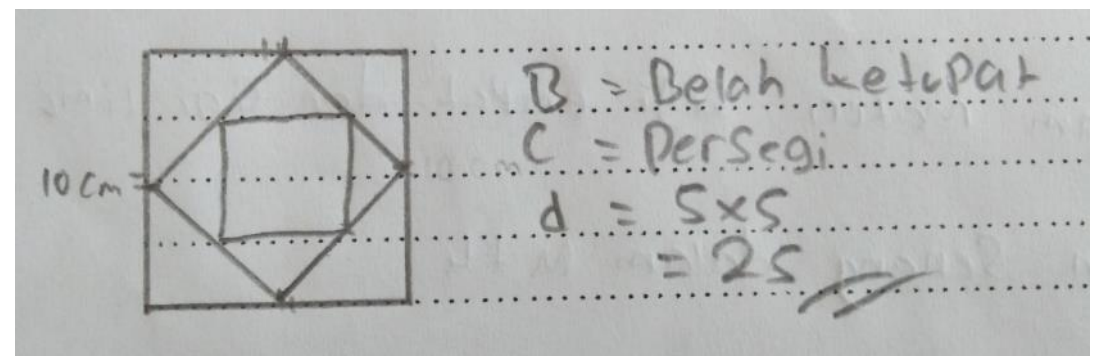

Gambar 11. Jawaban Siswa 2 
G : “Apakah bisa mengerjakan soal no.4?”

SII : "Bisa, bu."

G : "Dari manakah kamu mengetahui sisi bangun ke III?"

SII :"Hanya mengira-gira, bu"

G : "Apakah ada yang kurang dengan jawaban yang kamu tulis?"

SII : "tidak ada, bu"

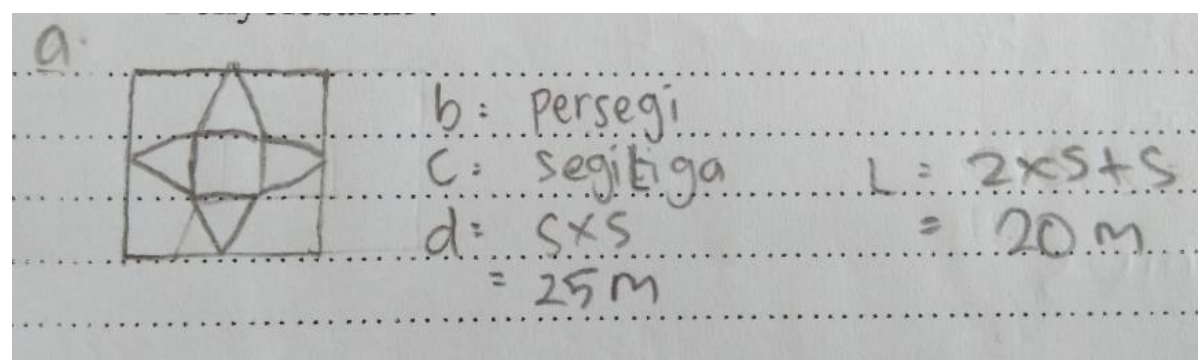

Gambar 12. Jawaban Siswa 3

G : “apakah ada kesulitan pada soal no 4 ?”

SIII :"saya bingung bu, kenapa ada bangun di dalam bangun"

G :"coba ikuti sesuai aturan yang sudah dibuat, dari 4a sampai 4d !"

SIII : "siap, bu”

Berdasarkan hasil wawancara dan hasil jawaban siswa pada nomer 4, dapat ditarik kesimpulan bahwa siswa I (KDT) berkemampuan tinggi dalam indikator flexibelity karena siswa tidak mengalami kesulitan menentukan nilai sisi yang tidak diketahui dengan konsep phytagoras serta lengkap menjawab beserta kelilingnya. Untuk siswa II (KDS) tergolong sedang dalam indikator ini karena siswa belum bisa menjelaskan darimana asal nilai sisi bangun III dan menentukan kelilingnya. Kemudian untuk siswa III (KDR) berkemampuan rendah dalam indikator flexibelity karena siswa masih mengalami kesulitan dalam menginterpretasikan soal kedalam bentuk gambar.

\section{Analisis Soal No. 5}

Pertanyaan no. 5: 
344 Eviliasani, Hendriana, \& Senjayawati, Analisis Kemampuan Berpikir Kreatif Matematis ...

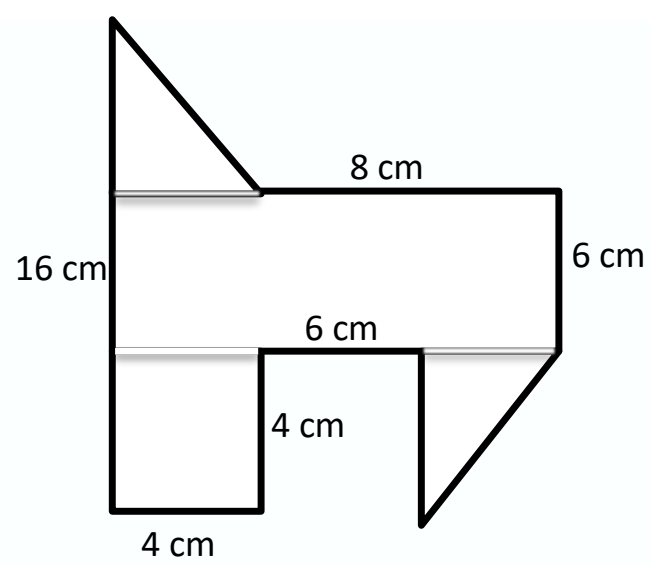

a. Dari gambar diatas, bangun datar apa sajakah yang dapat kamu lihat?

b. Buatlah dua kemungkinan cara menghitung luas bangun pada gambar di atas.

Indikator : Siswa dapat memecahkan masalah secara detail (elaboration/penguraian)

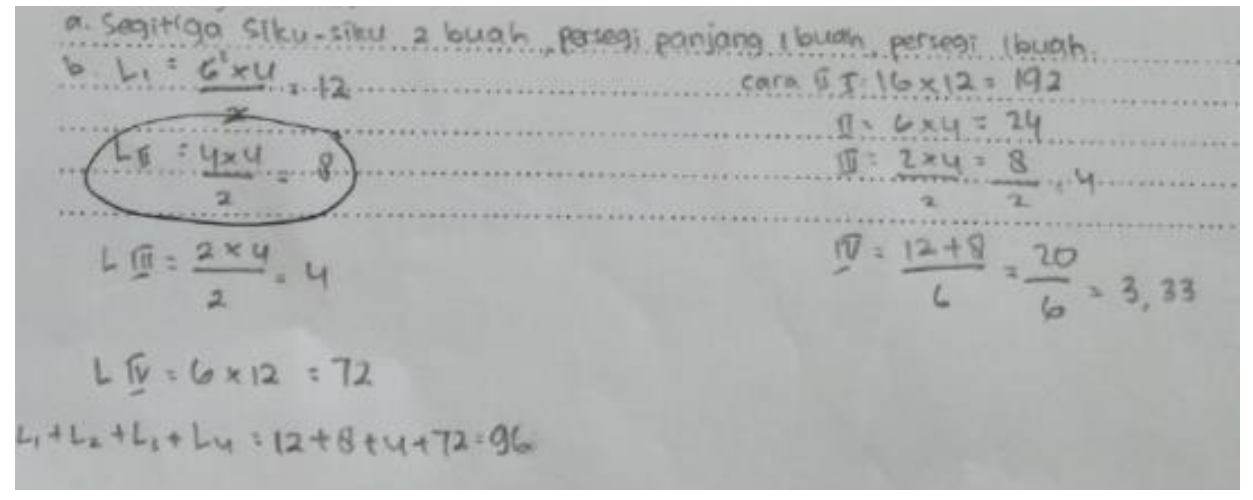

Gambar 13. Jawaban Siswa 1

G : "apakah terdapat kesulitan untuk soal no 5 ?"

SI : " "tidak ada, bu. Saya bisa."

G : "Darimanakah kamu mengetahui luas bangun astu dan lainnya?"

SI : "ada beberapa bangun yang saya lupa rumusnya, bu"

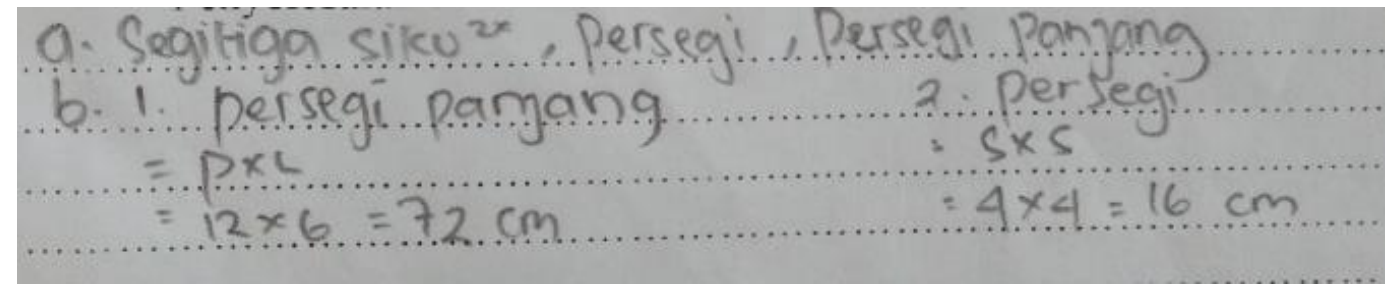

Gambar 14. Jawaban Siswa 2 
G : “Apakah bisa mengerjakan soal no.5 ?”

SII : "Bingung, bu."

G : "Dimanakah letak kebingungannya?"

SII :"Saya pusing melihat bangundatar yang terlalu banyak"

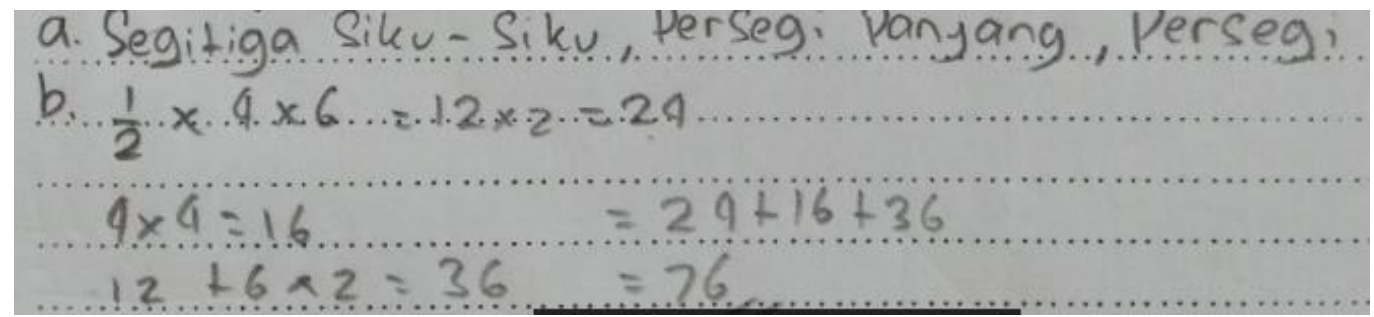

Gambar 15. Jawaban Siswa 3

G : “Apakah ada kesulitan pada soal no 5 ? Berapa bangun yang kamu lihat?”

SIII :"3 bangun, bu. Tapi saya kurang yakin"

G :"Coba perhatikan kembali bangunnya. Apakah hanya 3 bangun saja?"

SIII : "Siap,bu saya cek lagi"

Berdasarkan hasil wawancara dan hasil jawaban siswa pada nomer 5, dapat ditarik kesimpulan bahwa siswa I (KDT), II (KDS), maupun III (KDR) masih kesulitan menentukan sisi bangun yang belum diketahui dan mempartisi bangun segi banyak menjadi beberapa bangun datar. Maka pada indikator elaboration ini siswa masih dikatakan rendah.

\section{KESIMPULAN}

Berdasarkan pembahasan diatas, siswa dengan kepercayaan diri tinggi (KDT) akan memiliki kemampuan berpikir kreatif tinggi pada indikator fluency, flexibility, dan originality. Sedangkan siswa dengan kepercayaan diri sedang (KDS) akan memiliki kemampuan berpikir kreatif sedang pada indikator flexibility. Dan siswa dengan kepercayaan diri rendah akan memiliki kemampuan berpikir kreatif rendah pada indikator fluency, flexibility, originality, dan elaboration. Jadi dapat diambil kesimpulan bahwa kepercayaan diri mempengaruhi kemampuan berpikir kreatif matematis siswa.

\section{DAFTAR PUSTAKA}

Ayuni, R., Firmansyah, D., Senjayawati, E., \& Maya, R. (2018). Analisis Tingkat Kemampuan Berpikir Kreatif Siswa Dalam Menyelesaikan Permasalahan pada Materi Lingkaran, $I I(2), 139$ 148.

Dilla, S. C., Hidayat, W., \& Rohaeti, E. E. (2018). Faktor Gender dan Resiliensi dalam Pencapaian Kemampuan Berpikir Kreatif Matematis Siswa SMA. Journal of Medives, 2(1), 129-136.

Eftafiyana, S., Nurjanah, S. A., Armania, M., Sugandi, A. I., \& Fitriani, N. (2018). Hubungan Antara Kemampuan Berpikir Kreatif Matematis dan Motivasi Belajar Siswa SMP yang Menggunakan Pendekatan Creative Problem Solving, 2(2), 85-92. 
Hendriana, H. (2012). Pembelajaran Matematika Humanis Dengan Metaphorical Thinking Untuk Meningkatkan Kepercayaan Diri Siswa. Jurnal Infinity, 1(1), 90-103. Retrieved from http://ejournal.stkipsiliwangi.ac.id/index.php/infinity/article/view/9

Hendriana, H., Rohaeti, E. E., \& Hidayat, W. (2017). Metaphorical Thinking Learning and Junior High School Teachers' Mathematical Questioning Ability. Journal on Mathematics Education, 8(1), 55-64.

Hendriana, H., Hidayat, W., \& Ristiana, M. G. (2018, January). Student teachers' mathematical questioning and courage in metaphorical thinking learning. In Journal of Physics: Conference Series (Vol. 948, No. 1, p. 012019). IOP Publishing.

Hidayat, W. (2011). Meningkatkan Kemampuan Berpikir Kritis dan Kreatif Matematik Siswa Melalui Pembelajaran Kooperatif Think-Talk-Write (TTW) (Doctoral dissertation, Universitas Pendidikan Indonesia).

Hidayat, W. (2012). Meningkatkan Kemampuan Berpikir Kritis dan Kreatif Matematik Siswa SMA Melalui Pembelajaran Kooperatif Think-Talk-Write (TTW). In Seminar Nasional Penelitian, Pendidikan dan Penerapan MIPA.

Mahmudi, A., \& Sumarmo, U. (2004). Pengaruh Strategi Mathematical Habits of Mind (Mhm) Berbasis Masalah Terhadap Kreativitas Siswa. Cakrawala Pendidikan, XXX(2), 216-229.

Matematika, S. D. (1997). Konstruksi Teoritik Tentang Tingkat Berpikir Kreatif Siswa Dalam Matematika Tatag Yuli Eko Siswono, 1-10.

Muhamad, N. (2017). Pengaruh Metode Discovery Learning Untuk Meningkatkan Representasi Matematis Dan Percaya Diri Siswa. Jurnal Pendidikan, 9(1), 75-90. Retrieved from http://www.journal.uniga.ac.id/index.php/JP/article/view/79

Rahmi, S., Nadia, R., Hasibah, B., \& Hidayat, W. (2017). The Relation between Self-Efficacy toward Math with the Math Communication Competence. Infinity Journal, 6(2), 177182.

Ruseffendi, E. T. (2006). Pengantar Kepada Membantu Guru Mengembangkan Kompetensinya Dalam Pengajaran Matematika Untuk Meningkatkan CBSA. Bandung: Tarsito.

Sumarmo, U., Hidayat, W., Zukarnaen, R., Hamidah, M., \& Sariningsih, R. (2012). Kemampuan dan Disposisi Berpikir Logis, Kritis, dan Kreatif Matematik (Eksperimen terhadap Siswa SMA Menggunakan Pembelajaran Berbasis Masalah dan Strategi Think-Talk-Write). Jurnal Pengajaran MIPA, 17(1), 17-33.

Sumarmo, U., Mulyani, E., \& Hidayat, W. (2018). Mathematical Communication Ability and Self Confidence Experiment with Eleventh Grade Students Using Scientific Approach. JIML-Journal of Innovative Mathematics Learning, 1(1), 19-30.

Surya, E., Putri, F. A., \& Mukhtar. (2017). Improving Mathematical Problem-Solving Ability and Self-Confidence of High School Students Through Contextual Learning Model. Journal on Mathematics Education, 8(1), 85-94. https://doi.org/10.22342/jme.8.1.3324.85-94

Widiyanti, T. (2011). Pengaruh Gaya Belajar terhadap Kemampua Pemecahan Masalah Matematika. 